(c) 1986 ISIJ

\title{
レーザーによる表面改質加工
}

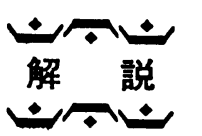

森

- 平*

\section{Laser Surface Modifications}

Kazuhira MORI

\section{1.はじめに}

今日までに発明されたレーザーの種類は百種類以上に なるといわれているが，加工用に用いられるレーザーは 大出力が必要であり，数種類に限定される. 表 1 に加工 用レーザーの種類と主な用途を示すが，国内で今日生産 に実用されているものはほとんどが $\mathrm{YAG} レ$ レー゙ーか $\mathrm{CO}_{2}$ レーザーである. 59 年度の国内におけるレーザー 加工機の出荷台数は約 1450 台 ${ }^{1)}$, 年率 $50 \%$ 強の伸び を示しているが用途はマイクロ除去，穴あけ，切断，溶 接が主で表面改質への用途はほとんど見られない.

しかし最近では高繰返しパルスの大出力エキシマレー ザーの研究も活発で, 平均出力 $200 \mathrm{~W}$ 級が開発され2), 半導体プロセスの光化学的表面処理加工が研究されてい る. また $\mathrm{CO}_{2}$ レーザーは連続発振で出力 $26.7 \mathrm{~kW}$ の 開発もなされ3), 大出力を必要とするレーザー熱処理加 エへの期待も高まつている．米国では既に自動車産業を はじめとして生産ラインにてレーザー焼入れ，クラッデ ィングが実用されており，国内でも今後急速に普及しは
じめると考える．ここではレーザー加工のこれからの応 用分野として期待されている材料の表面改質加工につい て紹介する.

\section{2. レーザー表面改質加工の原理}

\section{$2 \cdot 1$ 熱的加工の原理}

エネルギーを熱として利用するレーザーは波長が比較

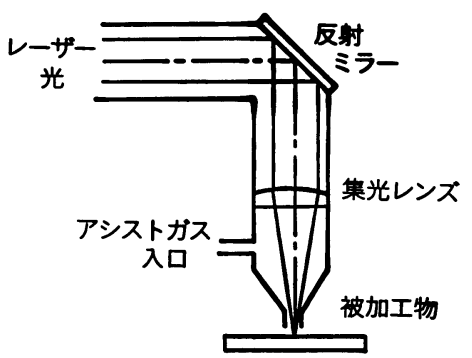

困 1 熱的加工に用いられるレーザー 加工へッドの構造

表 1 加工用レーザーの特性と用途

\begin{tabular}{|c|c|c|c|c|c|c|}
\hline \multicolumn{2}{|r|}{ レーザーの種類 } & 波長 ( $\mu \mathrm{m})$ & 発振形式 & 平均出力 (W) & 励起方式 & 用 \\
\hline \multirow{2}{*}{ 固 } & ルビー & 0.694 & 単一パルス & & キセノンランプ & （穴あけ・スポット溶接） \\
\hline & YAG & 1.06 & 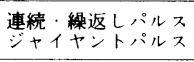 & $\sim 600$ & $\begin{array}{l}\text { キセノンランプ } \\
\text { クリプトンランプ }\end{array}$ & $\begin{array}{l}\text { トリミング・スクライビング・マーーキング } \\
\text { 穴あけ・溶接・はんだ付け・切断 }\end{array}$ \\
\hline \multirow{2}{*}{ 体 } & ガ ラ ス & 1.06 & 単一パルス & & キセノンランプ & スポット溶接・穴あけ \\
\hline & $\begin{array}{l}\text { アレクサン } \\
\text { ドライト }\end{array}$ & $\begin{array}{r}0.70 \\
\sim 0.82 \\
\end{array}$ & 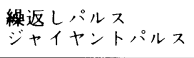 & $\sim 70$ & $\begin{array}{l}\text { キセノンランプ } \\
\text { クリプトンランプ }\end{array}$ & 穴あけ \\
\hline \multirow{2}{*}{ 気 } & $\mathrm{CO}_{2}$ & 10.6 & 連続・練返しパルス & $\sim 20000$ & $\begin{array}{l}\text { 放電 } \\
\text { 電ビーム (制御) }\end{array}$ & $\begin{array}{l}\text { 絇断·溶接 · 表面熱処理 } \\
\text { 微少除加工 }\end{array}$ \\
\hline & Ar & $\begin{array}{l}0.488 \\
0.514\end{array}$ & 連続波 & $\sim 18$ & 放電 & $\begin{array}{l}\text { 半導体加工 } \\
\text { 藵板 }\end{array}$ \\
\hline 体 & $\begin{array}{l}\text { ArF } \\
\text { KrF } \\
\text { XeC1 } \\
\text { XeF }\end{array}$ & $\begin{array}{l}0.193 \\
0.248 \\
0.308 \\
0.351\end{array}$ & パス & $\begin{array}{r}40 \\
200 \\
60 \\
15\end{array}$ & 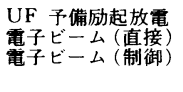 & $\begin{array}{l}\text { 材料の高純度精製 } \\
\text { 半䆃体の表面処理 } \\
\text { 材料合成 }\end{array}$ \\
\hline
\end{tabular}

昭和 60 年 11 月 14 日受付 (Received Nov. 14, 1985)（依頼解説）

* 三菱電機 (株) 名古屋製作所レーザー技術部品質保証課課長 (Quality Control Section, Raser Engineering Dept., Nagoya Works, Mitsubishi Electric Corp., 5-1-14 Yadaminami Higashi-ku Nagoya 461) 
的長い赤外レーザーを利用する. 太陽光線を虫めがオでで 集光し紙や木を然やすことができるが，レーザーは太陽 光線に比べ発散角の小さい平行光線であり，また色収差 を生じない単色光なので，集光特性がはるかに優れてい る.レーザーの波長と集光光学系の $\mathrm{F}$ 番号（レンズへの 入射ビーム径とレンズの焦光距離の比）などにより焦点 のスポット直径は異なるが, Y AG レーザーでは 0.01 $\mathrm{mm} \mathrm{CO}_{2}$ レーザーでは $0.1 \mathrm{~mm}$ 程度までの小さな径に 集光できる。また集光光学系入口でのビームのェネルギ 一密度が太陽光で $0.1 \mathrm{~W} / \mathrm{cm}^{2}$, レーザーでは最大 1000 $\mathrm{W} / \mathrm{cm}^{2}$ と大幅に異なるので，同一口径の集光光学系を 使用すれば焦点でのエネルギー密度は太陽光に比べ百万 倍以上にも達し $10^{8} \mathrm{~W} / \mathrm{cm}^{2}$ の高エネルギー密度が得ら れる。被加工物表面に照射されるレーザーのエネルギー 密度と照射時間を変化させることにより, 蒸発, 溶融あ るいは変態温度以上に加熱などの各種熱加工が可能とな る、レーザーは低いエネルギー密度で金属材料表面に照 射すると大部分の光が反射されてしまらので，加工効率 を高めるためには被加工物表面での反射を少なくする配 慮が必要である. 金属の熱処理加工では集光スポットビ 一ムの焦点径より幅の広い加工が要求され，ディフォー カスビームにして加工されることが多いので大出力のレ 一ザーを用いないと照射面でのエネルギー密度が低くな り反射光が多くなつてしまう。このような理由で今日金 属の熱処理加工の用途に使われるレーザーは，T業的に 最も大きな出力を連続的に発振できる $\mathrm{CO}_{2}$ レーザーに ほとんと限られている.

図 1 にレンズを用いた場合の代表的な加工へッドの構 造を示す. ノズルからはレーザーと共にアシストガス (熱処理加工の場合 Ar や乾燥空気を用いることが多い) を吹き出す。アシストガスはレーザー照射部より発生す るフュームや蒸発物を除去し，レーザーの被加工物への 吸収を良くするとともにシールドガスとしての役割を果 与.

\section{2 光化学的加工の原理}

短波長の紫外域高出力レーザーは，光子のエネルギー が赤外レーザーに比べ $20 〜 50$ 倍も大きく，材料を構成 する分子結合を選択的に光子のエネルギーで直接切断す
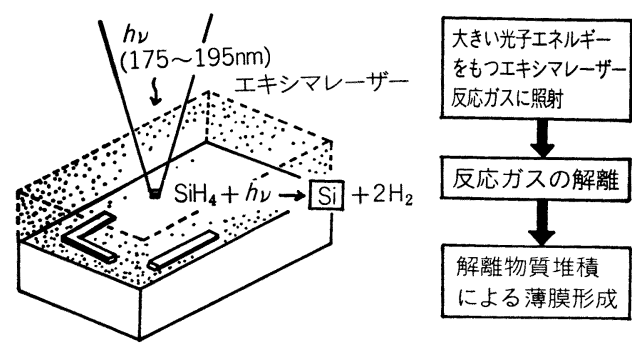

図 2 エキシマレーザーによるレーザー GVDの 原理
竖 2 レーザー丧面改質加工の分類

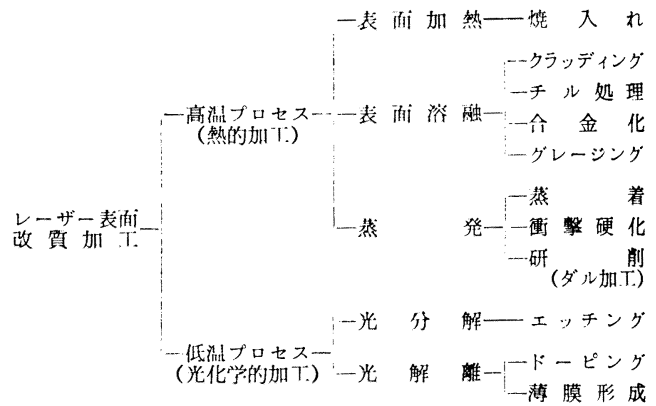

ることができる．赤外領域のレーザーが被加工物の局所 部を熱的に加熱，溶融，蒸発させて表面改質をおこなら のに対し，紫外領域のレーザーは光化学的な加工とな り，材料の温度を上げることなく加亡ができるのでプロ セスの低温化が図られる。

紫外域高出力レーザーとしてはアルゴンイオンレーザ 一，窒素レーザー，八ロゲン分子レーザーなどもあげら れるが，エキシマレーザーが効率，出力の点で最も優れ ている、エキシマレーザーはまだ工業用として使用する には出力が小さい, 出力バルスの繰返し数が小さい, 寿 命が短かいなどの問題があり车用の段階にはいたつてい ないが，短波長でありミクロン程度の集光も可能で高集 積度を必要とする半導体プロセスの加工用として大いに 期待されている.

図 2 にエキシマレーザーをもちいシランガス $\left(\mathrm{SiH}_{4}\right)$ 雾田気でシリコン半導体薄膜合成の例を示す. 七ラミッ クスなどの母材をシランガスに満たされた反応室に供給 し，シリコン膜を成膜したいところにレーザーを照射す ることにより，照射された個所だけガスが解離しシリコ ンが母材表面に堆積して膜が形成される。 今日までにレ ーザー CVD (Chemical Vapor Deposition) として

\begin{tabular}{|c|c|c|c|}
\hline ビーム & \begin{tabular}{|l|} 
発振器出口の \\
ヒ-
\end{tabular} & $\begin{array}{l}\text { ビームの } \\
\text { エネルギー分布 }\end{array}$ & 出力範囲 \\
\hline シングル & & & $2 \mathrm{~kW}$ 以下 \\
\hline マルチ & & & \\
\hline モード & & & $10 \mathrm{~kW}$ 以下 \\
\hline アニュラー & & & \\
\hline モード & & & $5 \sim 20 \mathrm{~kW}$ \\
\hline
\end{tabular}

闵 $3 \mathrm{CO}_{2}$ レーザーの各種ビームモード 


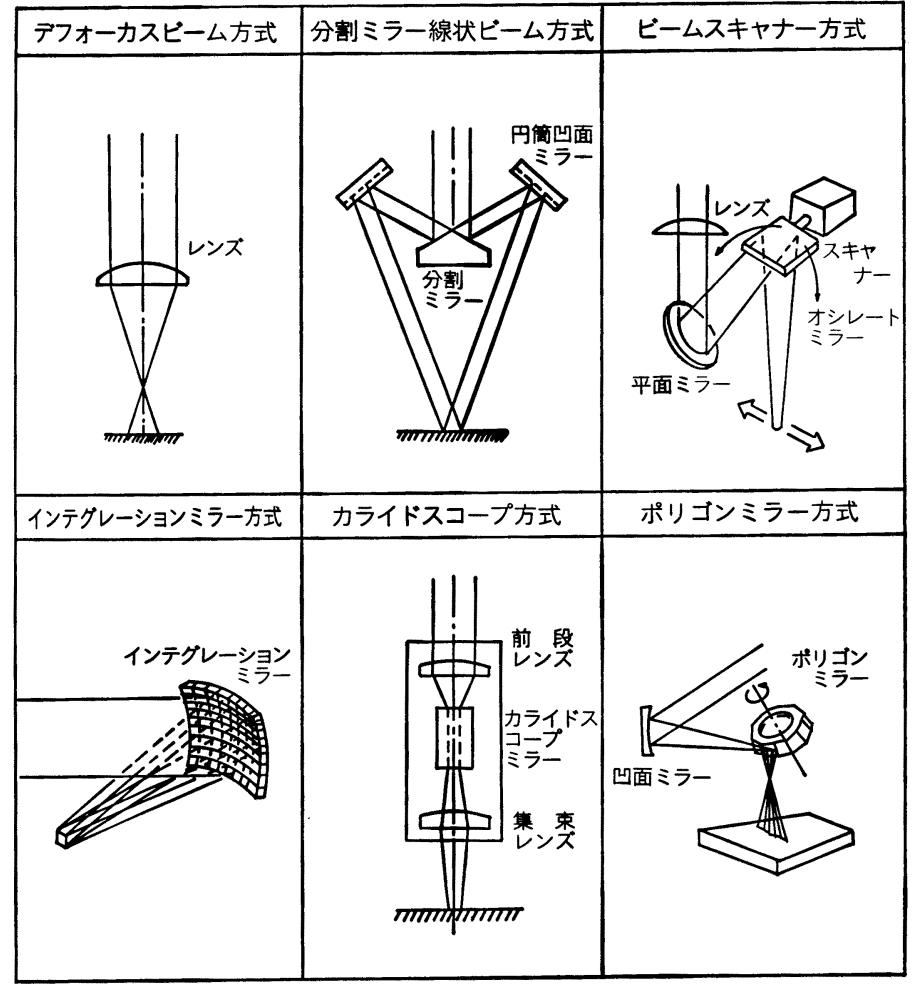

四 4 熱処理加工用各種レーザーヘッド \%式

$\mathrm{SiO}_{2}, \mathrm{InP}^{4)}, \mathrm{Al}^{5)}$ などの膜形成に成功している.

\section{3. レーザー表面改質加工の分類と特徴}

レーザーによる表面改質加工は，レーザー照射によつ て，材料表面に熱を加えて加工する高温プロセスと，低 温で光化学反応をおこさせる低温プロセスに分けられ る. 表 2 に実験的に可能性が確垫された各種の加工法を 示す.レーザーはランニングュストが高いので単に従来

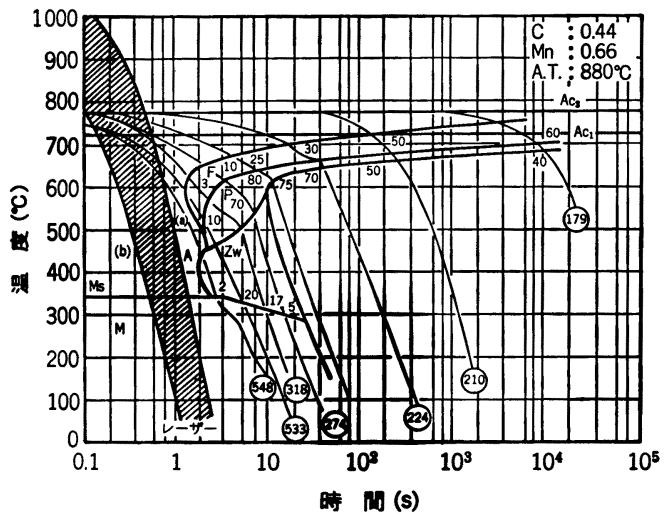

图 5 CCT 曲線上におけるレーザー焼入れの冷 却曲線7)

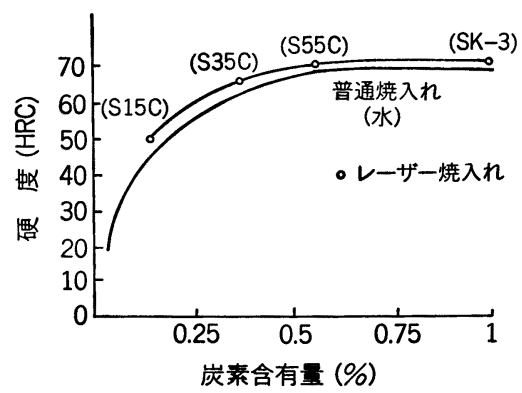

汹 6 レーザー焼入れと水焼入れの最高 硬さの比較

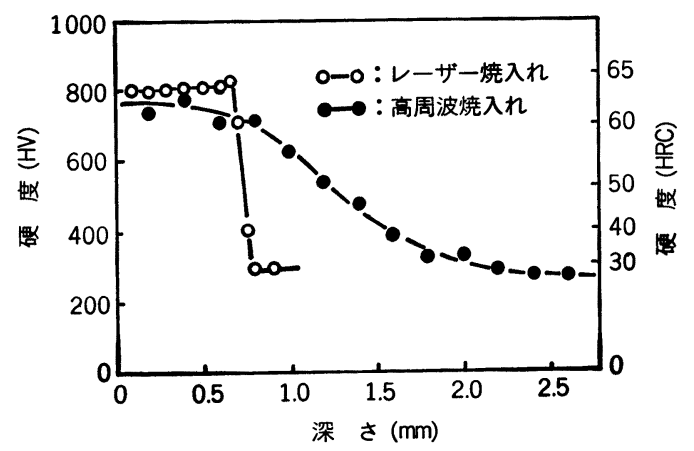

図 7 レーザー焼入れと高周波焼入れの硬度分布 ${ }^{7}$ 


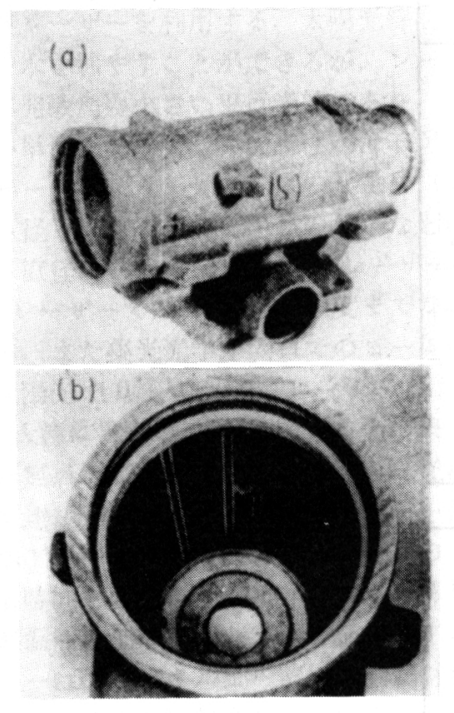

(a) 外観

(b) 線状の焼入れをおこなつた内面入

写真 1 内面部分焼入れされたフェライト可鍛鋳 鉄製のパワーステアリング・ギヤーハウジング

からある加工法を変更するだけでは採算が取れない、レ ーザーを用いたプロセスを採用するには，レーザー加工 の特徵をよく理解し, 従来の加工法では得られなかつた メリットを取り入れなければならない、レーザー加工の 特徵として下記の点がある。

（1）微少面積の薄い表層だけの加工が可能で入熱量 を少なくでき材料の変形，変質が少なくなり面倒な後加 工が軽減される。

（2）複雑な形状あるいは狭险部のある部品でも形状 的な制限を受けにくい.

（3）短時間で加工できオンライン処理が可能であ る.

（4）油，めつき液などの処理液を必要とせず無公害 環境で加工できる.

（5）エネルギーが精密にまた高速度に制御でき加工 面積, 深さが正確にコントロールできる.

（6）ビームを分割したり光路切換が可能でマルチス テーションの装置が容易に実現できる.

（7） 発振効率が低くイニシャルおよびランニングコ ストが高い.

（8）金属材料に対してはレーザーの反射率の高いも のが多く, 反射防止処理を必要亡するものがある.

（9）単位時間に加工できる面積が少ない.

以下米国で実用が始まつているレーザー熱処理加工に ついて述べる。

\section{4. 熱処理加工用の各種加エヘッド}

熱処理加工に使用される $\mathrm{CO}_{2}$ レーザーのビームは,
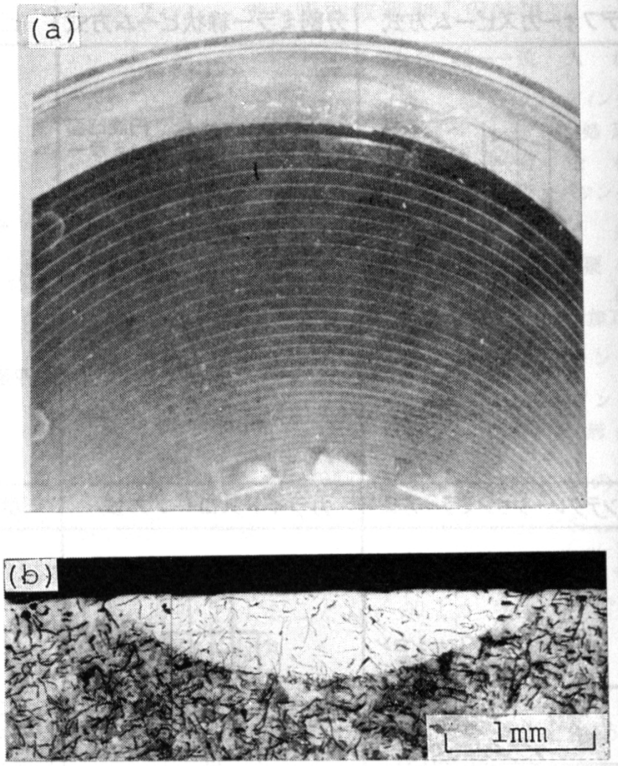

(a) 内面焼入状㦔

(b) 焼入部の断面マク口

写真 2 ディーゼルェンジンシリンダーの内面焼入部 共振器構成により図 3 に示すごとき各種のモードのもの がある、レンズあるいは四面鏡で光を集光し，加工に必 要なエネルギー密度が得られる適当なビーム径のところ で加工（デフォーカス法）すればよいが，ビームモード によりデフォーカス法だけでは必ずしも照射面でのエネ ルギー密度が均一にならない。 また $10 \mathrm{~mm}$ 以上の幅の 加工を抗こおおらとすると $5 \mathrm{~kW}$ 以下の出力でデフォー カス法を採用した場合エネルギー密度が低くなりすぎ, 反射が多くなつて加工効率が下がるので, ビーム径を加 工幅より小さくして, 高いエネルギー密度のスポット径 で必要な加工幅にビームを高速度（数百 $\mathrm{Hz}$ ) に振つて 加工するビームスキャナー方式が採用される。図4 亿各 種熱処理用の加工へッドの方式を示す.

\section{5. 各種熱処理加工法}

\section{$5 \cdot 1$ 表面焼入れ}

レーザービームを利用した焼入れでは，処理すべき局

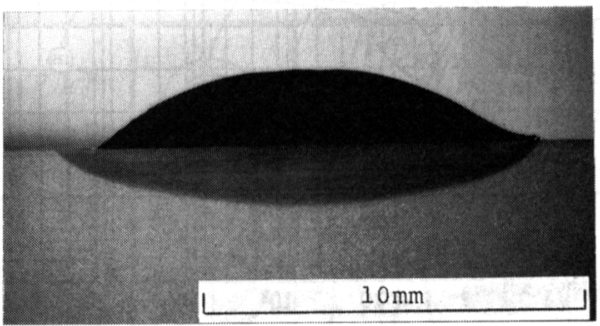

村材 : S35C, パウダ : Co 基自溶合金 レーザー出力 $: 15 \mathrm{~kW}$, 速度 $: 0.5 \mathrm{~m} / \mathrm{min}$

写真 3 レーザークラッディングの断面マクロ 
表 3 レーザー焼入れに用いられる各種コーティング材 と必要な性質

\begin{tabular}{|c|c|}
\hline コーティング材料 & コーティング材に要求される性倎 \\
\hline 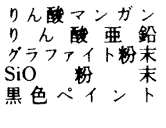 & 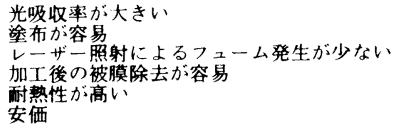 \\
\hline
\end{tabular}

部表面だけに高ェネルギー密度のレーザーを短時間照射 することで $\mathrm{A}_{1}$ 変態点以上の温度にし, 冷却はレーザー が通りすぎるとともに内部への熱拡散によつて起こる自 己冷却により行われ，パーライト変態することなく硬い マルテンサイトにするのである6).

レーザー焼入れの場合, 局所的に $10^{3}{ }^{\circ} \mathrm{C} / \mathrm{s}$ 程度の急 速加熱が抢こなわれ，そこから急速に自己冷却される.

一般の焼入れのよらに炭素を十分払散する時間がないの で在来の連続変態曲線（CCT 曲線）と同一には取り扱 えないが，目安としてS45Cにレーザー焼入れした実験 により得られた冷却速度を図 5 に示す7)。曲線 (a)は材 料の表面, (b) は内部の温度を示すが硬化層内部では $1 \mathrm{~s}$ 以内に $M s$ 点を通過し, フェライト変態開始線 $(F)$ や ベーナイト変態開始線 $(Z w)$ に交わらないで, 臨界冷却 曲線より早く完全マルテンサイト組織が得られることが わかる.

レーザー焼入れは水焼入れに比べても数倍以上も冷却 速度が速く，炭素鋼の焼入れにおいて最高硬さはより高 くなる. 図 6 に $1.5 \mathrm{~kW}$ 出力のレーザーでビームスキャ

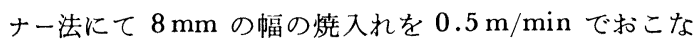
つた場合の $0.15 \sim 1.0 \%$ 炭素鋼の最高硬さを炉焼入れ で得られたものとの此較で示す、レーザー焼入れでは焼 入硬度は炭素の量および加工速度で決まり，他の添加元 素の影響はほとんど受けない. 炭素含有量 $1.0 \%$ まで のすべての領域で從来最も硬度が上がつた水焼入れより 高い硬度が得られている. 図 7 に S43C 鋼の高周波焼入 れとの比較で硬度分布を示す7). 高周波焼入れに比べて 焼入深さは浅くなつているが，レーザー焼入れのほらが 不完全焼入部が少なく, 最高硬度が HV 硬さで 50 程 度大きくなつていることがわかる。

$\mathrm{CO}_{2}$ レーザーは燒入れに使用する $10^{3} \sim 10^{5} \mathrm{~W} / \mathrm{cm}^{2}$ の エネルギー密度では，金属表面での反射率が $90 \%$ 程度 と高いため，金属面のままでは効率よく加工できない。 そのため $10.6 \mu \mathrm{m}$ の光を良く吸収する表 3 に示すごと き各種の吸収剂を被加工物表面に被覆する。吸収率の向 上，金属表面の溶融防止では効果が上がつているが，焼 入後照射部にスラグ状のものが付着したり，表面粗さが 覀くなり後処理で研削などが必要なものが多く今後より 前後処理が簡単な吸収剂の開発が必要である.

レーザー焼入れの実用例では GM 社のパワーステア リングギヤーハウジングの例は有名で $0.5 \sim 1 \mathrm{~kW}$ 出力
のレーザーを用いてフェライト可鍛鋳鉄製ハウジング内 面に幅 $1.5 \sim 2.5 \mathrm{~mm}$, 深さ $0.25 \sim 0.35 \mathrm{~mm}$ の線状焼入 れを 5 本形成することで, $1.5 \mu \mathrm{m}$ 以内の仕上代で済む 耐摩耗性の高い焼入れがなされている8 例を示す. 写真 2 は同じく GM 社がディーゼルエンジ ンのシリンダーの内面ライナーに $5 \mathrm{~kW}$ 出力のレーザー を用いて幅 $2.5 \mathrm{~mm}$, 深さ $0.5 \mathrm{~mm}$ の局部焼入れをらせ ん状に抏こないピストンリングによる摺動摩耗を減少さ せた例である。

\section{$5 \cdot 2$ クラッティング}

レーザークラッディングは普通鋼の表面に耐食性，耐 摩耗性，耐熱性等にすぐれた合金材を粉末あるいはフィ ラーワイヤーなどの形で母材表面に供給し，レーザーに より溶融し肉盛する・レーザーは母材表面をごくわずか だけ溶融させることができるので, $0.1 〜 0.2 \%$ の極低希 䣋率で実現でき, $\mathrm{Co}, \mathrm{Ni}, \mathrm{Fe}, \mathrm{WC}$, アルミナなどの実施 例が報告9)されている．入熱量が少なすぎると（加工速 度が速くなりすぎると）ビードが盛り上がり母材との接 触角が大きくなり, 層を重悋た際, ビードの継ぎ目に欠 陷が出やすいので接触角が $30^{\circ}$ 以下になるような形状 のビードが好ましい. 写真 3 に $15 \mathrm{~kW}$ の出力でクラッ ディングした断面を示す.

\section{3 チル処理}

鋳鉄表面をレーザーで溶融させ，自己冷却で急速に冷 却凝固させることにより $\mathrm{HV} 600$ 以上の硬度を得るこ とができる.アーク熱源によるチル化に比べ入熱量が少 なく変形が少ないメリットがある.しかし予熱なしでチ ル化をおこならと冷却時に割れが発生する. 硬度は少し 低下寸るが，200 $\mathrm{C}$ 以上の予熱をすると割れの発生が防 止できる10).

\section{4 合金化処理}

合金化したい素材表面に粉末状，めつき，蒸着などに よつて添加したい合金元素を配置し、レーザー光を照射 すると部品表面の薄い層を容易に溶融できるので，短時 間 $\left(10^{-3} \sim 10 \mathrm{~s}\right)$ に元素が払散して薄い合金層が得られ る.まだ研究段階であるが, $\mathrm{Cr}, \mathrm{Ni}, \mathrm{W}, \mathrm{V}, \mathrm{Mn}, \mathrm{C}$ な ど多くの元素を使つた合金化の実験成功例がある ${ }^{11)}$.

通常の製造方法では作りだせない非平衡の合金相を局 所的に形成できる特徵もあり, 技術確立ができれば経済 性に十分のる用途も出てくるものと思われる.

\section{6. 結}

レーザーによる表面改質は半導体, 自動車部品, 一般 産業機器の部品など広い分野への可能性を秘めている.

必要な個所だけを最少限のエネルギーを加えて局所的 に処理することは，大幅な材料費の低減を実現できる付 加価值の高い加工法であり，今後急速に普及するものと 予想される。この解説がレーザー表面改質の実用化に多 少とも参考になれば幸いである。 


\section{交献}

1) レーザー加工栈市場の現状と今後の二ーズ㩆狊 (矢野経済研究所編) (1985), p. 3

2 ) $R$. $R$. Butcher and T. S. Fahlen: CLEO '84 Technical digest (1984), p. 202

3 ) $N$. Tabata, $H$. Nagai, $H$. Yoshida, $M$. Hishil, $M$. Tanaka, $Y$. Myoi and $T$. Akiba: CLEO '84 Technical digest (1984), p. 54

4 ) $V . M$. Donnelly, M. Geva, $J$. Long and $R$. F. Karlicek: Appl. Phys. Lett., 44 (1984), p. 54

5 ) T. McGrath: Solid State Technol December
(1983), p. 168

6 ）川泳博通：レーザ加 L:技術 (1985)，p. 61

7 ) 菊池正夫, 久旧秀犬, 森津和夫：小松技報， 26 (1980), p. 30

8 ) $J . A$. Wineman and $J . E$. Miller: Metal Progress, 111 (1977), p. 38

9 ) $D . S$. Gnanamuthu: Optical Engineering, 19 (1980), p. 783

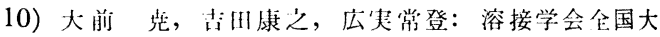
会講演概要 33 (1983), p. 30

11) F. D. Seaman and $D . S$. Gnanamuthu: Metal Progress, 108 (1975), p. 67 